\title{
A diversidade do cooperativismo brasileiro e catarinense
}

\author{
Dimas de Oliveira Estevam* \\ Max Richard Coelho Verginio**
}

\begin{abstract}
Resumo
O cooperativismo surgiu como um movimento social e econômico alternativo às desigualdades sociais provocadas pelo sistema capitalista no início da Revolução Industrial. Atualmente, está presente nos mais diversos segmentos econômicos (agricultura, indústria, comércio, crédito e serviços). Com a intenção de compreender o seu papel para o desenvolvimento socioeconômico brasileiro e catarinense, busca-se conhecer a diversidade deste movimento. Para isso, no presente artigo, objetiva-se identificar os segmentos econômicos em que atuam as cooperativas brasileiras e catarinenses. Para alcançar o objetivo proposto, tem-se como procedimento metodológico a pesquisa descritiva realizada a partir de levantamento de informações na Relação Anual de Informações Sociais (RAIS). Utilizou-se o nível de seção da Classificação Nacional de Atividades Econômicas (CNAE), além de dados obtidos nas organizações de representações do cooperativismo. Pelos números da RAIS, no Brasil, 2015 registrou 14.027 cooperativas, enquanto em Santa Catarina havia 1.253 cooperativas registradas. Em relação a outros estados, Santa Catarina se destaca por representar 8,93\% das cooperativas brasileiras.
\end{abstract}

Palavras-chave: cooperativismo; cooperativas; desenvolvimento

\section{The diversity of cooperativism in Brazil and in Santa Catarina}

\begin{abstract}
Cooperativism emerged as an alternative social and economic movement to the social inequalities provoked by the capitalist system at the beginning of the Industrial Revolution. Currently, it is present in the most diverse economic segments (agriculture, industry, commerce, credit and services). With the intention of understanding its role for the socioeconomic development of Santa Catarina, it is sought to know the diversity of its movement. For this, in the present article, the objective is to identify the economic segments in which Brazilian and Santa Catarina cooperatives operate. To reach the proposed objective, the methodological procedure is the descriptive research carried out based on the collection of information in the Annual Social Information Relation (RAIS). It was used the section level of the National Classification of Economic Activities (CNAE), in addition to data obtained from organizations representing cooperatives. By the RAIS numbers, in Brazil, 2015 registered 14,027 cooperatives, while in Santa Catarina there were 1,253 registered cooperatives. In relation to other states, Santa Catarina stands out as representing $8.93 \%$ of Brazilian cooperatives.
\end{abstract}

Keywords: cooperativism; cooperatives; development

JEL Classification: J54, P13

\footnotetext{
* Professor do curso de Ciências Econômicas e do Programa de Pós-graduação em Desenvolvimento Socioeconômico da Unesc (PPGDS). E-mail: doe@unesc.net

** Graduando em Ciências Econômicas da Unesc e Bolsista do FUMDES (Fundo de Apoio à Manutenção e ao

Desenvolvimento da Educação Superior). E-mail: verginio@unesc.net
} 


\section{Introdução}

O cooperativismo tem grande importância socioeconômica, na atualidade, mas é um fenômeno pouco estudado, principalmente na área da economia. Por consequência, às vezes, o tema tem sido tratado sob os aspectos doutrinários ou pela ótica empresarial. Além dos equívocos das análises, muitas vezes se tem uma visão distorcida de seu processo histórico e de sua constituição, bem como um desvirtuamento de sua natureza. Nesse aspecto, existe uma carência de estudos sobre o tema.

Algumas análises buscam demonstrar que o cooperativismo remonta aos primórdios da humanidade e que o ato de cooperar é inerente ao ser humano. Entretanto, o cooperativismo deve ser entendido como um movimento social resultante das consequências do surgimento do liberalismo econômico nos séculos XVIII e XIX. Nesse período, muitas pessoas não tinham como sobreviver, tendo que buscar formas alternativas para se inserir no mercado e, também, meios para melhorar suas condições de vida.

O movimento cooperativista ganhou seus traços definitivos na Inglaterra, em 1843, a partir dos princípios e da experiência de Rochdale. Entre os princípios do cooperativismo, destaca-se a importância do trabalho conjunto, a ajuda mútua, a participação das pessoas com o intuito de difundir ideias e aumentar o engajamento e aproveitamento do associado dentro das cooperativas, e, principalmente, o sentido social e democrático na tomada de decisões. Apesar disso, com o tempo, essas características foram sofrendo desvirtuamento, alguns de seus princípios foram caindo em desuso - seja do ponto de vista do espírito cooperativista, seja do ponto de vista da própria organização cooperativa -, o que fez com que muitas cooperativas se comportassem como empresas, afastando-se dos seus princípios iniciais (BENIN; BENIN, 2015).

Tradicionalmente, a cooperativa tem sido definida como associação de pessoas com o propósito de cooperar umas com as outras. O objetivo dessa união é a solução de problemas econômicos comuns por meio da solidariedade. Dessa maneira, o cooperativismo é um sistema econômico e social que busca, por meio da cooperação, a organização coletiva e uma distribuição mais equilibrada de riquezas.

Nesse sentido, a cooperativa é definida por Crúzio (2002) como a união de trabalhadores ou profissionais de diversos setores, que se associam por iniciativa própria, sendo livre seu ingresso, desde que os interesses individuais em produzir, comercializar ou prestar um serviço não sejam conflitantes com os objetivos gerais da cooperativa. Dessa forma, as cooperativas se diferenciam das demais sociedades por terem características próprias: adesão voluntária; capital social variável; uma pessoa, um voto; dependem de um 
número mínimo de sócios para sua constituição, não de capital; o rateio das sobras e/ou perdas é proporcional à produção de cada associado; entre outras especificidades. Nessa perspectiva estão a complexidade das organizações cooperativas e, fundamentalmente, seus princípios ideológicos.

O objetivo deste artigo é apresentar, de modo geral, a diversidade do cooperativismo catarinense, além de identificar os principais segmentos econômicos onde ele atua no estado de Santa Catarina.

Cabe destacar que dados sobre o cooperativismo são disponibilizados periodicamente pelo órgão fiscalizador, de acordo com o ramo de atividade (produção, crédito, comércio, outros). Esses números são específicos à análise de questões como a admissão e demissão de pessoal, as flutuações do quadro social e o volume comercializado. Já as séries estatísticas, como as dos Censos, equiparam as cooperativas às demais empresas e oferecem informações específicas muito esparsas, concentradas nas cooperativas agrícolas (GAIGER, 2013).

A par desses dados, a Organização das Cooperativas Brasileiras (OCB) dispõe de informações sobre os diversos ramos do cooperativismo, principalmente quanto ao quadro social, aos postos de trabalho e à movimentação financeira. Entretanto, os dados são fornecidos pelas cooperativas filiadas à Entidade, sem caráter compulsório, não englobando a totalidade das cooperativas existentes no País e estando eles sujeitos a omissões e a erros. Em relação aos números oficiais, estes não permitem discriminar as particularidades das práticas cooperativas (GAIGER, 2013).

Com o intuito de atingir o objetivo proposto, tem-se como procedimento metodológico o estudo de caso do cooperativismo catarinense, o qual foi escolhido por ser representativo em nível de país. Para Yin (2005), o estudo de caso é uma investigação empírica. Para tanto, fez-se um apanhado sobre a trajetória do cooperativismo em fontes bibliográficas. Já em relação às bases de dados, obtiveram-se informações em diversas fontes, como RAIS/CAGED, OCB, OCESC, entre outras.

O cooperativismo, quando desenvolvido dentro de seus princípios, possibilita ao associado ter acesso aos direitos políticos, sociais e econômicos. Em sua trajetória, as cooperativas passaram por transformações profundas, cujas mudanças provocaram alterações, as quais vão de encontro com os seus preceitos, como, por exemplo, o surgimento de facetas de não cooperação, a competitividade e a centralização do poder. Para que possam sobreviver no contexto atual, tais mudanças fazem com que se naturalizem posturas mais egocêntricas, ao invés de colaborativas, no interior dessas associações, e até com que muitas delas atuem como empresas, afastando-se dos seus princípios norteadores. 
Com isso, o cooperativismo brasileiro e catarinense pode ser classificado, a grosso modo, em dois grupos distintos: o primeiro formado pelas cooperativas vinculadas à $\mathrm{OCB}$, e o segundo pelas cooperativas organizadas como parte do movimento da economia solidária. $\mathrm{O}$ artigo, além desta seção introdutória, está estruturado em outras duas seções, nas quais discorre, em primeiro lugar, sobre a trajetória do cooperativismo, e depois sobre o cooperativismo catarinense.

\section{A trajetória do cooperativismo}

Desde a sua origem, o cooperativismo desempenhou uma função importante no desenvolvimento socioeconômico europeu. A Cooperativa de Consumo dos "Probos Pioneiros de Rochdale" foi a pioneira entre as cooperativas, tendo surgido num importante centro têxtil, no norte da Inglaterra, em 1844, onde foi fundada por 28 operários (SINGER, 2002).

Nesse sentido, alguns dos princípios iniciais e conhecidos do cooperativismo foram imortalizados por aquela cooperativa, tais como: cada membro tem direito a um voto, independentemente da quantidade investida; o número de associados é aberto e o capital emprestado; a cooperativa paga uma taxa de juros fixa e as sobras são divididas entre os sócios em proporção às compras; as compras efetuadas têm que ser à vista e os produtos vendidos não podem ser adulterados; há promoção de educação cooperativa; deve haver neutralidade nas questões políticas e religiosas.

Em sua trajetória, esses princípios se transformaram em uma espécie de "mito" do cooperativismo - baseado na cooperação, nas decisões conjuntas, nos benefícios a todos os sócios, sem fins lucrativos -, e são temas recorrentes no cooperativismo atual. Do ponto de vista de sua estrutura organizacional, no cooperativismo, desde a sua fundação, a forma "cooperativa" se manteve inalterada. Contudo, no que diz respeito às questões relacionadas ao seu conteúdo, às dinâmicas de produção e às formas de solidariedade, há uma expressiva diversidade (BENIN; BENIN, 2015).

Para os autores supracitados, essa variabilidade aponta para duas tendências, uma solidariedade de tipo patronal (formada por pequenas e médias empresas ou médios e grandes proprietários rurais) e uma solidariedade dos trabalhadores. Nessa ambivalência, as cooperativas podem ser pensadas de forma análoga à de uma chave que abre diversas portas: da mesma forma que podem servir a objetivos e propósitos dos trabalhadores, também podem ser utilizadas por segmentos empresariais ou por grandes estabelecimentos rurais. 
$\mathrm{Na}$ realidade, segundo Rios (1989), o cooperativismo, longe de superar as diferenciações socioeconômicas, pode reproduzi-las, contradizendo sua ideologia niveladora. Nessa lógica, cada classe social pode ter a sua cooperativa. Isso significa dizer que, ao invés de as diferenças entre as classes diminuírem, podem até se agravar. Isso ocorre porque a cooperativa, ao crescer, possibilita a seus dirigentes prestígio social e poder político.

Dessa forma, as cooperativas se desenvolvem ante um dilema entre a solidariedade e a competição no mercado. Dada a dinâmica produtiva determinada pela troca mercantil, as cooperativas, sob esse ponto de vista, não se diferenciam em relação às empresas. Nesse aspecto, se a prioridade for a solidariedade interna, tendem a se frustrar economicamente, precisamente se seguirem seus princípios fundadores ou se optarem pelo crescimento no qual precisam priorizar a competição externa, perdendo suas características iniciais e caracterizando-se em um cooperativismo pragmático e de resultados (RIOS, 1989; BENIN; BENIN, 2015).

Isso ocorre porque, estando a cooperativa dentro do sistema produtivo atual, tendo que concorrer e produzir de acordo com as exigências do mercado, os seus princípios acabam e sua aplicação fica limitada. Desse modo, a organização da produção, bem como a amplitude da tomada de decisão ou o poder dos sócios, vê-se diante da contradição de governar a si mesma como empresária. Por conseguinte, para conseguir competir no mercado, ela acaba tendo que seguir os padrões de organização e de gestão tipicamente burocráticos das empresas, em detrimento dos princípios autogestionários do cooperativismo. (BENIN; BENIN, 2015).

Nesse sentido, conforme Benin e Benin (2015), a autogestão fica comprometida por ficar restrita a limitadas variáveis, tendo os cooperados que se adaptar às condições do mercado, ao padrão produtivo e mercadológico vigente, centrados na competição e não na lógica da solidariedade e da distribuição dos resultados. Desse modo, as cooperativas, principalmente as de produção, não conseguem avançar no sentido da autogestão e da distribuição das sobras. Sendo assim, mesmo que os princípios do cooperativismo estejam inscritos, na realidade será cumprida apenas a formalidade, não havendo envolvimento e participação ativa dos cooperados, mas sim a necessidade crescente da contratação de trabalho assalariado, o que gerará uma realidade próxima das características das organizações heterogestionárias.

É preciso ser considerado também o caso da agricultura, por meio da qual as cooperativas proporcionam ganhos de escala, tanto na realização de compras de insumos, como na comercialização das colheitas. Desse modo, a cooperativa aumenta as vantagens para 
os produtores rurais que, ao produzirem isoladamente, podem usufruir dos ganhos de escala proporcionado pela cooperação (sejam grandes ou pequenos proprietários) (BENIN; BENIN, 2015).

No caso dos produtores rurais, como produzem de forma isolada, a cooperação acontece na esfera da comercialização. Outra característica dessas cooperativas é o grande número de funcionários para realizar as atividades produtivas, já que os cooperados possuem duplo papel: de proprietários e de gestores da cooperativa. Para Zylbersztajn (2002), o problema desse modelo de cooperativismo está no princípio da autogestão, pois, em uma cooperativa, o fato de o trabalhador ser também proprietário dos meios de produção, isso o induz a estruturar a sua atividade produtiva como um empresário e, ao mesmo tempo, a participar de uma sociedade gerida pelos princípios da cooperação, tida como benigna. Nos casos em que a gestão é conduzida pelos cooperados, a cooperativa perde vantagens advindas da especialização, por isso que a gestão deveria ser gerida por profissionais.

Ainda sobre a questão do controle, ressalta-se que, além da separação entre propriedade e controle, sugerida pelo autor acima, também existe a separação entre controle e execução (trabalhadores, gerentes e cooperados), o que é considerado uma estrutura contraditória aos princípios do cooperativismo, pois, devido à preocupação maior com os resultados, os princípios cooperativistas se tornam um entrave às estratégias a serem adotadas por essas cooperativas, criando um contraste com organizações de outra natureza, como no caso das empresas que têm como finalidade o lucro e com as quais essas cooperativas competem no mercado.

Stahl e Schneider (2013) alertam para outros obstáculos que causam a degeneração do cooperativismo de modo geral e que podem dificultar a aplicabilidade dos princípios cooperativistas. Seriam eles: a pouca rotatividade da diretoria; a falta de identificação e participação dos associados; ambiente pouco participativo nas assembleias; debilidade dos vínculos de adesão dos associados com a organização; inadequada relação de poder e conhecimento técnico-administrativo; impasses de capitalização das cooperativas comparadas às empresas privadas; a falta de intercooperação e cooperação; síndrome da prosperidade que afasta o sentimento cooperativista dos associados.

Cabe ressaltar que, em relação à participação na tomada de decisões, devem ser consideradas outras variáveis, como o aumento do número de associados, cujo crescimento poderá acarretar prejuízos às cooperativas. Para Bialoskorski Neto (2007), o aumento de sócios poderá trazer prejuízos para a participação social dos cooperados, uma vez que poderá promover o aumento de custos devido à assimetria das informações. O autor ressalta que 
quanto mais significativos forem esses custos, menor será o estímulo para tal participação. Dessa forma, o crescimento do quadro social torna o processo de decisões mais complexo. Como exemplifica o autor, uma cooperativa de 20 associados possui mais expressão nas assembleias gerais se comparada a uma cooperativa com 1.000 sócios, pois, quanto maior for o número de sócios, maior será o distanciamento destes da cooperativa.

Para Singer (2002), os fatores econômicos influenciam na participação dos sócios, principalmente quando a cooperativa está economicamente fragilizada ou quando algo de errado está acontecendo. Nos momentos de crises, os cooperados se sentem na obrigação de consertar os erros e organizar a casa, mas quando ocorre uma situação inversa, o problema pode ser outro. Conforme o autor, cooperativas que vão bem podem vir a apresentar um quadro oposto: a lei do menor esforço poderá concentrar o poder de decisão nas mãos dos gestores e a organização poderá escorregar, sem perceber, para uma prática de heterogestão. Singer (2002) também chama a atenção para a tendência da degeneração por parte das cooperativas e de seus princípios autogestionários, que se transformará em uma realidade de participação muito mais formal do que efetiva.

Diante dessas questões, segundo Pinho (1982), o cooperativismo tendeu ao desvirtuamento em decorrência dos problemas resultantes da própria evolução da cooperativa, que deixou de ser uma simples associação mutualista para se transformar em uma complexa organização social. Ou seja, a cooperativa incorpora os problemas da empresa, embora se inspire nos ideais cooperativistas de democracia direta, mas numa complexa sociedade, tecnicamente diferenciada e burocraticamente administrada. Assim, do ponto de vista socioeconômico, a cooperativa se modernizou, desvirtuando-se dos seus princípios básicos.

Dessa maneira, conforme Pinho (1982), como associado-empresário-usuário, o sócio renuncia parte de sua autonomia e de seu poder para se unir cooperativamente aos outros sócios, submetendo-se aos princípios de igualdade e da gestão democrática, bem como à formação de um patrimônio de utilidade coletiva, mas impartilhável entre os associados. Segundo a autora, ele aceita essas condições impostas pelas assembleias gerais em troca de certas vantagens, como a redução de custos, a economia de escala, a ampliação do mercado, a realização solidária de empreendimentos que transcendem ao âmbito de sua capacidade técnica e financeira, o aumento de serviços econômicos e sociais à sua disposição, entre outros benefícios.

Além disso, nessas situações, segundo Pinho (1982), o cooperado não está preocupado com as mudanças socioeconômicas da sociedade, mas apenas interessado em realizar sua atividade econômica com mais eficiência, ou seja, é nesse sentido que busca a 
cooperativa. Esse enfoque da cooperativa como técnica organizatória eficaz na promoção do desenvolvimento econômico tornou-se significativo, especialmente nos últimos anos. $\mathrm{Na}$ visão da autora, paralelamente ao cooperativismo de inspiração rochdaleana, desenvolve-se um "cooperativismo sem Rochdale” na acepção doutrinária, que utiliza a cooperativa como técnica empresarial.

Cabe ressaltar que no Brasil o cooperativismo é um movimento social significativo, mas com diferentes posicionamentos ante o mercado e a questão social, os quais, de acordo com Bialoskorski Neto (2012), podem ser definidos em dois grupos predominantes e distintos. O primeiro deles é formado por cooperativas tradicionais, organizadas por intermédio da OCB, movimento representado por cooperativas que foram fundadas desde meados do século XX, portanto, organizadas por cooperativas já estabelecidas no mercado, com foco mais no econômico. O segundo é formado por cooperativas denominadas "sociais", que se organizam como parte da economia solidária, com foco na questão social, as quais são organizadas pela União das Cooperativas de Agricultura Familiar e Economia Solidária (UNICAFES). Suas cooperativas não estão vinculadas à $\mathrm{OCB}$, mas possuem um número significativo de organizações, com importância social relevante.

Atualmente, embora exista essa dubiedade no cooperativismo brasileiro em manter sua identidade ante o mercado, que trata as cooperativas como grandes empresas, e ao mesmo tempo não abrir mão de seus princípios cooperativistas fundamentais, vê-se que ela está mais nítida nas grandes cooperativas agrícolas, que congregam cooperados que não podem ser considerados "pequenos produtores". Essas cooperativas, apesar de serem consideradas distantes do cooperativismo tradicional, são para Singer (2002) entidades híbridas, ou seja, metade solidárias e metade capitalistas, porque de alguma forma preservam muitos dos princípios do cooperativismo. Pinho (2001) complementa essa ideia ao afirmar que compatibilizar o idealismo cooperativista com a eficiência e a competitividade exigidas numa economia globalizada é a difícil missão do cooperativismo atual.

Enfim, o movimento cooperativo se desenvolveu em todas as suas bases. Dessa forma, os trabalhadores, não satisfeitos em apenas constituí-lo, estavam também preocupados em estabelecer toda a base de ideias e regras gerais para a manutenção desse sistema, ao passo que as cooperativas cresceram, ganharam consistência e formaram instituições concretas com elevado teor social, que foi difundido por vários países, chegando ao Brasil. 


\section{O cooperativismo brasileiro e em Santa Catarina}

O cooperativismo brasileiro teve seu início por volta de 1841, na comunidade de Palmital, no município de São Francisco do Sul, SC (atualmente município de Garuva), uma colônia de produção e consumo com base nos ideais cooperativos. A experiência teve suas atividades encerradas em 1943 (ETGETO et al., 2005).

De acordo com Etgeto et al. (2005), no Brasil, oficialmente, o cooperativismo surgiu em 1847, ano em que foi fundada a Colônia Tereza Cristina na região sul do Paraná. Embora tenha tido curta duração, sua contribuição foi de grande relevância na difusão dos ideais cooperativistas no País. A colônia não foi uma cooperativa nos moldes tradicionais, mas uma organização comunitária que funcionou com base nos princípios do cooperativismo. Outras experiências semelhantes foram florescendo no Brasil, como as sociedades de Socorro Mútuo, que surgiram a partir de 1850 e que também não eram cooperativas, mas que contribuíram significativamente para a consolidação do movimento no País.

Com a chegada dos imigrantes, principalmente alemães e italianos, sobretudo no sul do Brasil, utilizando-se das experiências de seus países de origem, os ideais cooperativistas começaram a ser mais difundidos. Segundo os autores supracitados, muitas das comunidades buscaram solucionar seus problemas de consumo, crédito e produção por meio da cooperação. A partir disso, em 1889, foi fundada uma cooperativa em Rio dos Cedros, SC, e outra em Ouro Preto, MG. Dois anos depois (1891), uma terceira cooperativa foi fundada em Limeira, SP - considerada a primeira cooperativa formalizada do País. Em 1895, foi a vez do município de Caramagibe, PE.

Em 1908, descendentes de imigrantes italianos fundaram a Cooperativa Agrícola de Rio Maior (Cooperprima), no município de Urussanga, SC (ETGETO et al., 2005). Essas experiências contribuíram substancialmente para a difusão dos ideais cooperativistas pelo País. A partir disso, as cooperativas prosperaram e tiveram grande expansão, sendo as décadas de 1950 e 1960 o período de grande crescimento das cooperativas brasileiras. Atualmente, apenas em relação às cooperativas filiadas à OCB (2015), vê-se que elas são mais de 6,8 mil, de acordo com a Tabela 1, distribuídas em todos os seus segmentos produtivos, chegando a um total de 11,5 milhões de associados e a empregar 360 mil trabalhadores diretos. Em termos regionais, no Sul do País, o cooperativismo emprega por volta de 151 mil trabalhadores; no Sudeste, $97 \mathrm{mil}$; e no Centro-Oeste, cerca de 20 mil. Em relação aos estados, o Paraná gera mais emprego, aproximadamente 61 mil; o Rio Grande do Sul, em torno de 52 mil, e São Paulo, 48 mil. Atualmente, as cooperativas vinculadas à OCB representam cerca de $50 \%$ da produção agropecuária do País. 
As cooperativas brasileiras estão divididas em treze ramos de atividades, conforme a Tabela 1, cujos mais representativos são os seguintes: o agropecuário, com 1.528, representa $23,44 \%$ e $50,11 \%$ dos empregos gerados, seguido pelo de transporte (1.164) e pelo de crédito (980); ele também é o que tem mais sócios, 54,55\%. Já entre as regiões, destacam-se a Sudeste (2,3 mil), a Nordeste $(1,7$ mil) e a região Sul (1 mil). Os estados com mais cooperativas são os seguintes: São Paulo (949), Bahia (788) e Minas Gerais (775). Em relação à exportação, o estado de São Paulo participou com 33,9\%, seguido por Paraná, com 29,2\%, por Minas Gerais, com 12,6\%, e por Santa Catarina, com 6,2\%.

O número de associados às cooperativas, segundo a OCB (2016), representa 5,7\% da população brasileira. Se somadas as famílias dos cooperados, estima-se que o cooperativismo envolva mais de 46 milhões de pessoas, representando 22,8\% da população. Embora esse número seja significante, em países como o Canadá, por exemplo, o percentual de cooperados em relação à população adulta é de aproximadamente $80 \%$, índice superior em relação à realidade do Brasil.

A tabela 1, abaixo, sintetiza a representatividade do cooperativismo brasileiro vinculado à $\mathrm{OCB}$, por ramo de atividades, número de cooperativas, número de cooperados e empregos diretos gerados.

Tabela 1 - Composição do sistema cooperativo brasileiro - por ramo de atividades: 2016

\begin{tabular}{|c|c|c|c|c|c|c|}
\hline Ramo & Cooperativas & $\%$ & Associados & $\%$ & Empregados & $\%$ \\
\hline Agropecuário & 1.543 & 23,44 & 993.564 & 7,82 & 180.891 & 50,11 \\
\hline Consumo & 124 & 1,88 & 2.958 .814 & 23,29 & 13.919 & 3,86 \\
\hline Crédito & 980 & 14,89 & 6.931 .144 & 54,55 & 46.824 & 12,97 \\
\hline Educacional & 282 & 4,28 & 52.069 & 0,41 & 3.953 & 1,10 \\
\hline Especial & 8 & 0,12 & 350 & 0,00 & 7 & 0,00 \\
\hline Habitacional & 283 & 4,30 & 123.568 & 0,97 & 945 & 0,26 \\
\hline Infraestrutura & 133 & 2,02 & 973.974 & 7,67 & 6.363 & 1,76 \\
\hline Mineral & 80 & 1,22 & 74.172 & 0,58 & 239 & 0,07 \\
\hline Produção & 268 & 4,07 & 12.534 & 0,10 & 1.932 & 0,54 \\
\hline Saúde & 818 & 12,43 & 245.960 & 1,94 & 92.181 & 25,54 \\
\hline Trabalho & 877 & 13,32 & 204.340 & 1,61 & 1.586 & 0,44 \\
\hline Transporte & 1.164 & 17,68 & 133.886 & 1,05 & 12.132 & 3,36 \\
\hline Turismo e Lazer & 22 & 0,33 & 1798 & 0,01 & 23 & 0,01 \\
\hline Total & 6.582 & 100 & 12.706 .173 & 100 & 360.995 & 100 \\
\hline
\end{tabular}

Contudo, quando se trabalha com outras fontes de informações, é possível verificar que o sistema cooperativo brasileiro é bem mais abrangente do que as cooperativas vinculadas à OCB. Ao analisar os dados disponíveis na RAIS/MTE, por exemplo, vê-se que o número de estabelecimentos passa de 14 mil, o número de vínculos empregatícios, de 388 mil, e, em 
termos de massa salarial, foi movimentado mais de um bilhão de salários mínimos (aproximadamente 10 bilhões de reais), conforme tabela 2 a seguir.

Tabela 2 - Composição do cooperativo brasileiro - por ramo de atividades: 2015

\begin{tabular}{|c|c|c|c|c|c|c|}
\hline \multirow[b]{2}{*}{ IBGE Subsetor } & \multirow{2}{*}{$\begin{array}{l}\text { Massa salarial } \\
\qquad(\mathrm{SM})^{1}\end{array}$} & \multirow[b]{2}{*}{$\%$} & \multirow{2}{*}{$\begin{array}{l}\text { Estabele- } \\
\text { cimento }\end{array}$} & \multicolumn{3}{|c|}{ Qtd Vínculos } \\
\hline & & & & $\%$ & Ativos & $\%$ \\
\hline Instituição Financeira & $383.901,16$ & 34,16 & 4.704 & 33,54 & 99.307 & 25,55 \\
\hline Alimentos e Bebidas & $206.294,23$ & 18,35 & 900 & 6,42 & 92.950 & 23,92 \\
\hline Comércio Atacadista & $166.191,40$ & 14,79 & 2.385 & 17,00 & 51.682 & 13,30 \\
\hline Médicos Odontológicos Vet. & $142.969,39$ & 12,72 & 935 & 6,67 & 53.945 & 13,88 \\
\hline Comércio Varejista & $77.448,26$ & 6,89 & 1.648 & 11,75 & 35.472 & 9,13 \\
\hline Adm. Técnica Profissional & $26.060,27$ & 2,32 & 266 & 1,90 & 5.827 & 1,50 \\
\hline Transporte e Comunicações & $25.476,70$ & 2,27 & 1.299 & 9,26 & 12.463 & 3,21 \\
\hline Agricultura & $22.676,44$ & 2,02 & 623 & 4,44 & 10.693 & 2,75 \\
\hline Aloj. Comunicação & $20.141,46$ & 1,79 & 640 & 4,56 & 6.194 & 1,59 \\
\hline Serviço de Utilidade Pública & $19.307,24$ & 1,72 & 122 & 0,87 & 4.968 & 1,28 \\
\hline Indústria Química & $11.017,78$ & 0,98 & 29 & 0,21 & 4.228 & 1,09 \\
\hline Ensino & $8.301,02$ & 0,74 & 240 & 1,71 & 4.162 & 1,07 \\
\hline Outros $^{2}$ & $14.172,62$ & 1,26 & 236 & 1,68 & 6.715 & 1,73 \\
\hline Total & $1.123 .957,97$ & 100,00 & 14.027 & 100,00 & 388.606 & 100,00 \\
\hline
\end{tabular}

1Média salarial no ano, em salários mínimos

²Vínculos Ativos inferiores a 1\%: 12 - Indústria de Calçados, 11 - Indústria Têxtil, 15 - Construção Civil, 01Extrativa Mineral, 03 - Indústria Metalúrgica, 04 - Indústria Mecânica, 02 - Produção Mineral não Metálico, 07 Madeira e Mobiliário, 09 - Borracha, Fumo, Couros, 08 - Papel e gráfica, 05 - Elétrico e Comunicação, 06 Material de Transporte. Fonte: RAIS/MTE (2017)

Os dados apresentados anteriormente, tanto os disponibilizados pela OCB quanto os pela RAIS, não permitem discriminar as particularidades das práticas cooperativas no País. Como é o caso, por exemplo, dos Empreendimentos Econômicos Solidários (EES), mapeados pelo Sistema Nacional de Informações em Economia Solidária (SIES) e pela Secretaria Nacional de Economia Solidária (SENAES), em parceria com o Fórum Brasileiro de Economia Solidária (FBES). O Mapeamento de Economia Solidária realizado em 2013 identificou 19.708 empreendimentos distribuídos entre 2.713 municípios, abrangendo todo o País. Os EES foram classificados no Mapeamento em quatro tipos de organizações: associações, cooperativas, grupos informais e sociedades mercantis (SILVA; CARNEIRO, 2016).

Com base no mapeamento, a forma de organização predominante de EES era a associação, com $60 \%$ do total, seguida pelos grupos informais, com 30,5\%, e pelas cooperativas, com 8,8\%, além do percentual residual de sociedade mercantil, com menos de $1 \%$. As associações estavam presentes, principalmente, em áreas rurais, e representavam $69 \%$ desses empreendimentos. Os grupos informais e as cooperativas eram mais frequentes em áreas urbanas (59\% e 46\%, respectivamente). Cabe salientar que os EES resultam, em certa 
medida, da persistência de formas históricas de solidariedade. Segundo Gaiger (2013), muitas vezes, eles são pouco conhecidos e mal reconhecidos.

O número de associados a algum tipo de EES chegou a 1.423.631, o que demonstra que essas organizações englobaram um grande contingente de pessoas. Em média, eram 73 associados por empreendimento; além disso, a maioria dos EES era formada, em média, por vinte sócios $(41,7 \%)$. Outras $(32,6 \%)$ possuíam entre 21 e 50 sócios, como pode ser verificado na tabela 3. Em relação às cooperativas, o número médio de cooperados por unidade era de 250, embora as cooperativas correspondessem a apenas 8,8\% dos EES mapeados; além disso, elas respondiam por $29,9 \%$ do total de sócios envolvidos nesses empreendimentos. Em relação à contratação de mão de obra, 2.822 dos EES (14,3\%) contratavam trabalhadores não associados (SILVA; CARNEIRO, 2016).

Tabela 3 - Distribuição dos EES por número de sócios

\begin{tabular}{lrr}
\hline \multicolumn{1}{c}{ Faixa de número de sócios } & Total & $\%$ \\
\hline Até 6 sócios & 2.802 & 14,22 \\
De 7 a 19 sócios & 4.567 & 23,17 \\
De 20 a 39 sócios & 5.390 & 27,35 \\
De 40 a 59 sócios & 2.518 & 12,78 \\
De 60 a 99 sócios & 2.032 & 10,31 \\
De 100 ou mais sócios & 2.304 & 11,69 \\
Ignorados & 95 & 0,48 \\
\hline \multicolumn{1}{c}{ Total } & 19.708 & 100 \\
\hline
\end{tabular}

Fonte: DIEESE - Observatório Nacional da Economia Solidária e do Cooperativismo; maio de 201.

Ao realizar a análise sobre o cooperativismo brasileiro, não se teve a pretensão de esgotar o tema, mas apresentar, mesmo que brevemente, o quão complexo é o sistema cooperativista em sua dimensão mais ampla. O subitem a seguir analisa as experiências das cooperativas catarinenses.

\subsection{O cooperativismo em Santa Catarina}

Em Santa Catarina, o cooperativismo teve sua representatividade oficializada em 1964, ano em que foi instituída a Associação das Cooperativas de Santa Catarina (ASCOOP). Posteriormente, em 1971, a Ascoop foi transformada na Organização das Cooperativas do Estado de Santa Catarina (OCESC), órgão representativo das cooperativas catarinenses, vinculado ao sistema OCB. Contudo, como já foi referido anteriormente, as primeiras cooperativas de Santa Catarina foram fundadas no século XIX (SABINO et al., 2009).

As cooperativas filiadas ao sistema Ocesc (2015) somam um total de 260 cooperativas. Os ramos de atividades com mais organizações são as cooperativas de crédito 
(25\%), seguidas das agropecuárias (20\%). Segundo a Ocesc (2015), essas cooperativas representam 1,908 milhão de famílias associadas e geram 56.311 empregos diretos, com um faturamento de aproximadamente 27 bilhões de reais anuais, o que significa mais de $10 \%$ do PIB catarinense. A figura 1 apresenta o número de cooperados por ramo de atividade: as cooperativas de crédito possuem mais de um milhão de associados, representam $45 \%$ do total de cooperados, empregam mais de duzentos trabalhadores, sendo que 57\% deles estão vinculados às cooperativas agropecuárias.

Figura 1 - Número de cooperados por ramo de atividade em 31/12/2015

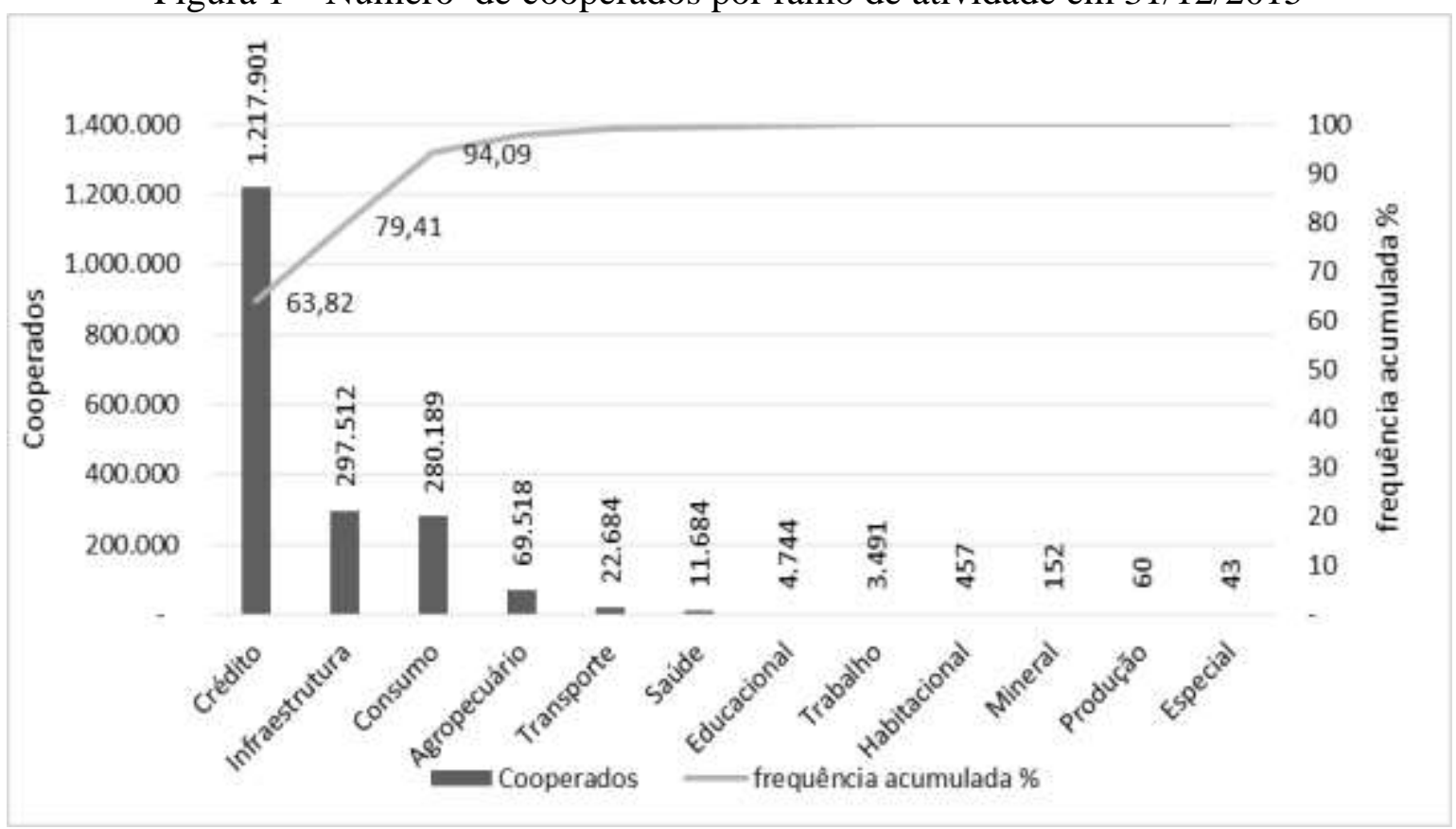

Fonte: OCESC (2015)

Ainda com base nos dados da Ocesc (2015), 64\% do faturamento das cooperativas foram obtidos pelas cooperativas agropecuárias, seguidas pelas de saúde (17,3\%). Já as de crédito $(6,1 \%)$ e de transporte $(6,1 \%)$ ocuparam juntas o terceiro lugar. As cooperativas do ramo agropecuário, apesar de ocuparem o segundo lugar em termos de representação numérica, $53(20 \%)$ contra $65(25 \%)$ das do ramo de crédito, contudo, têm o maior faturamento entre todas as cooperativas do Estado.

No Brasil, as cooperativas do ramo agropecuário filiadas à OCB são pouco mais de 1.500 organizações, com cerca de 880.000 cooperados. Em Santa Catarina, como apresentado anteriormente, são 53 cooperativas, as quais contam com 58.824 filiados. A maioria das cooperativas agropecuárias está localizada no Meio-Oeste e no Oeste catarinense $(61,5 \%)$ (OCESC, 2015). 
No entanto, quando se analisam os dados da RAIS/MTE, constata-se que o número de cooperativas catarinenses é bem superior às 260 registradas no sistema Ocesc. A figura 2 demonstra a evolução do número de cooperativas em Santa Catarina. Em 2002, somavam 667, passando para 1.253 estabelecimentos em 2015, classificados com natureza jurídica de cooperativa neste mesmo ano.

Figura 2 - Evolução do número de cooperativas em Santa Catarina - 2002 a 2015

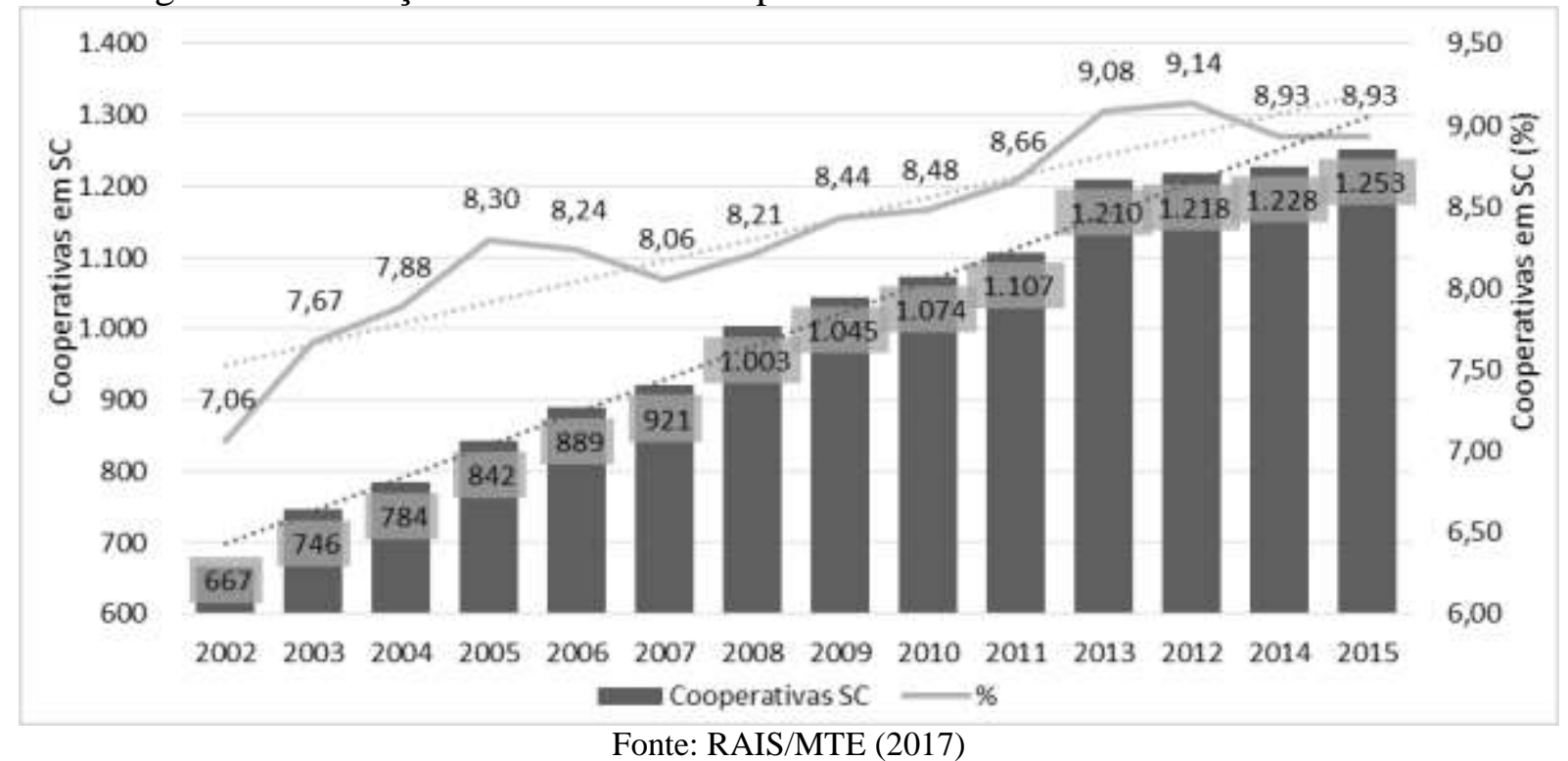

A figura 3, abaixo, apresenta o número de vínculos ativos por Mesorregião em Santa Catarina. Cabe destacar a Mesorregião Oeste com maior número de vínculos, seguida pelo Vale do Itajaí e pelo Sul catarinense. 
Figura 3 - Número de vínculos ativos por mesorregião em Santa Catarina

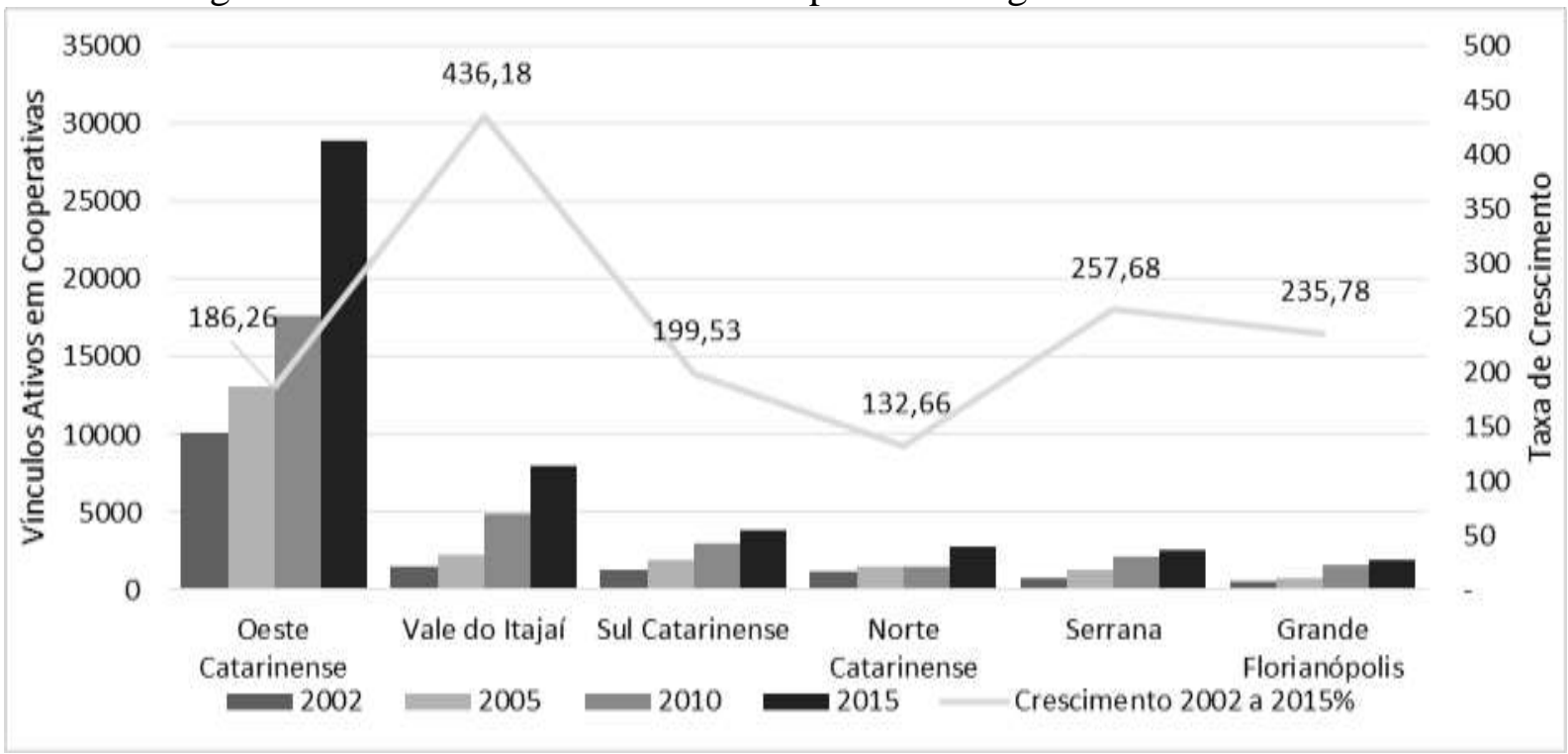

Fonte: RAIS/MTE (2017)

Quando se analisa o vínculo dos trabalhadores em termos rurais e urbanos, verifica-se a predominância de aglomerações no Interior, chegando a 46.965 vínculos em 2015, contra 1.092 do Urbano. Entretanto há uma expansão consistente nos dois sentidos, o Interior cresceu em média $9 \%$ ao ano e o Urbano a uma taxa anual de $13 \%$ até 2013 . A partir de 2014, houve uma redução de $35 \%$ no biênio seguinte, conforme pode ser verificado na figura 4 a seguir.

Figura 4 - Vínculos ativos por tipo de aglomeração no Interior ou no Urbano em SC: 2015

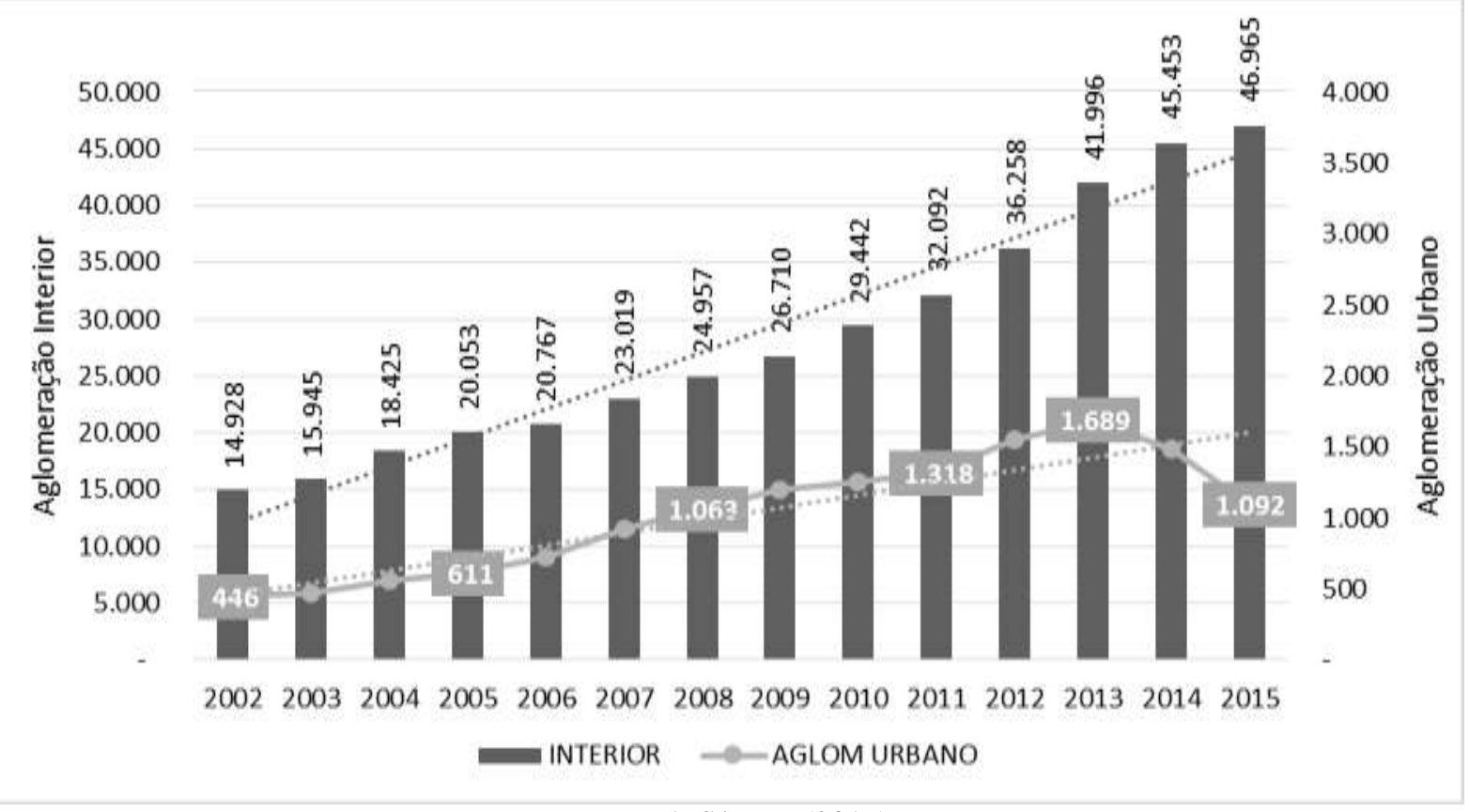

Fonte: RAIS/MTE (2017) 
Com base na classificação de setores de atividade econômica do IBGE (Instituto Brasileiro de Geografia Estatística), apresentam-se os dados referentes à distribuição de 48.057 Vínculos Ativos por setor econômico (linha-eixo da direita da figura 5). Também são apresentados 1.253 estabelecimentos de cooperativas nas barras-eixo da esquerda da figura 5 . Nessas barras-eixo, destacam-se quatros setores que concentram $84 \%$ da força de Vínculos Ativos em 2015, seguindo esta ordem decrescente: Alimentos e Bebidas, 38,85\%, Instituição Financeira, 22,54\%, Comércio Varejista, 12,41\% e Comércio Atacadista, 10,08\%. Quanto aos principais estabelecimentos, estes estão com $24,58 \%$ e $24,10 \%$, Instituição Financeira e Comércio Atacadista, respectivamente, seguidos de Comércio Varejista, com 19,31\%, e Alimentos e Bebidas, com 9,58\%.

Figura 5 - Vínculos ativos e estabelecimentos por subsetor do IBGE, 2015

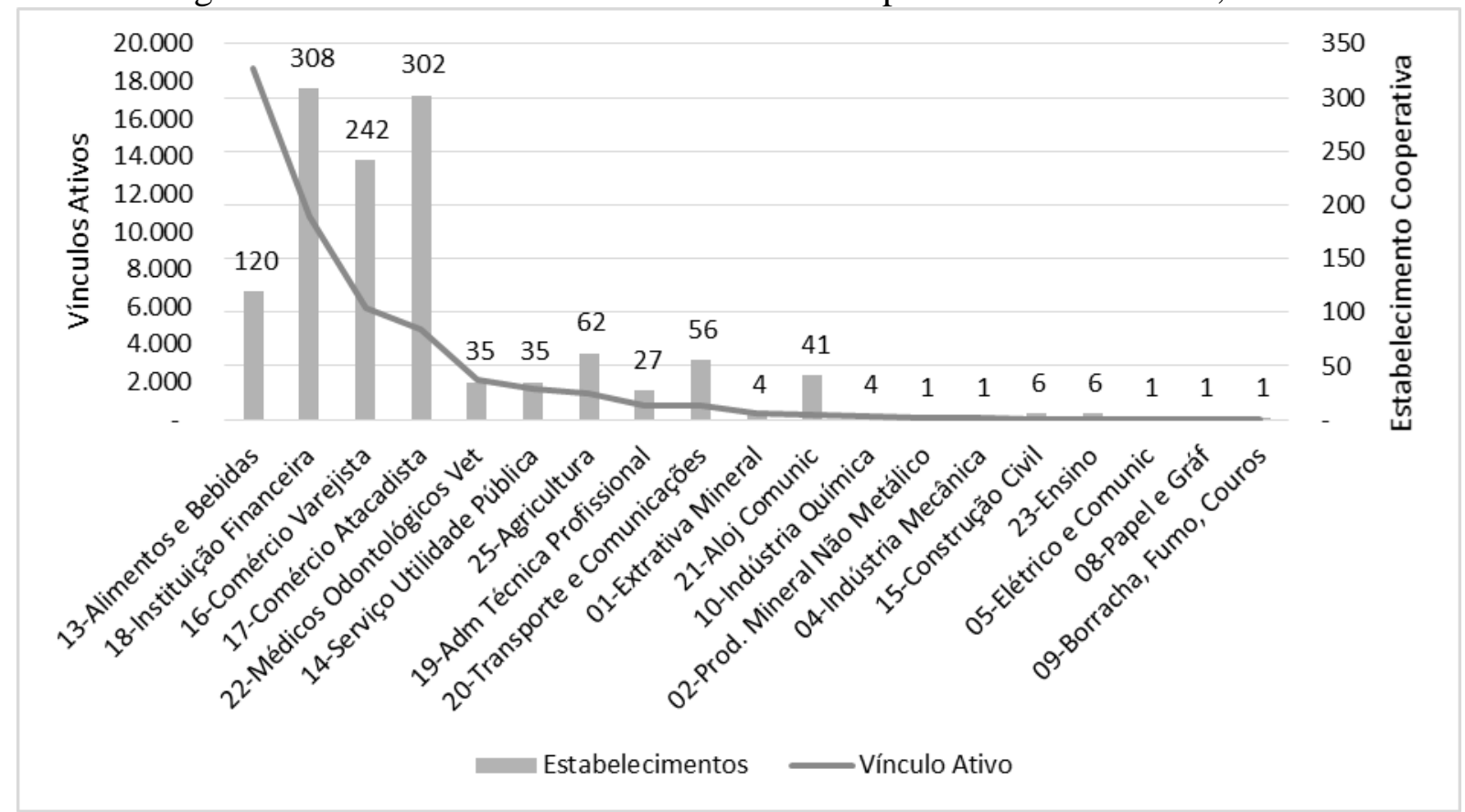

Fonte: RAIS/MTE (2017)

Em relação ao sexo do trabalhador, as mulheres vêm conquistando espaço nas cooperativas catarinenses. Em 2002, eram 34,04\%. Desse ano em diante, até 2015, teve uma taxa média de crescimento de 3,32\%, ou seja, chegou a $47 \%$ da força de trabalho contratada. Em virtude de ter se estabilizado o crescimento, houve equilíbrio entre mulheres e homens. Já em relação aos setores, os que mais contrataram foram os de Alimentos e Bebidas, com 7.970 mulheres em 2015, com um crescimento de 269\% no período, e os de Instituições Financeiras, com 7.270 mulheres contratadas em 2015 e um crescimento de $1.722 \%$. Como 
pode ser observado na figura 6 , as mulheres vêm ampliando sua participação no mercado de trabalho cooperativista catarinense.

Figura 6 - Sexo do trabalhador Santa Catarina: 2002 a 2015

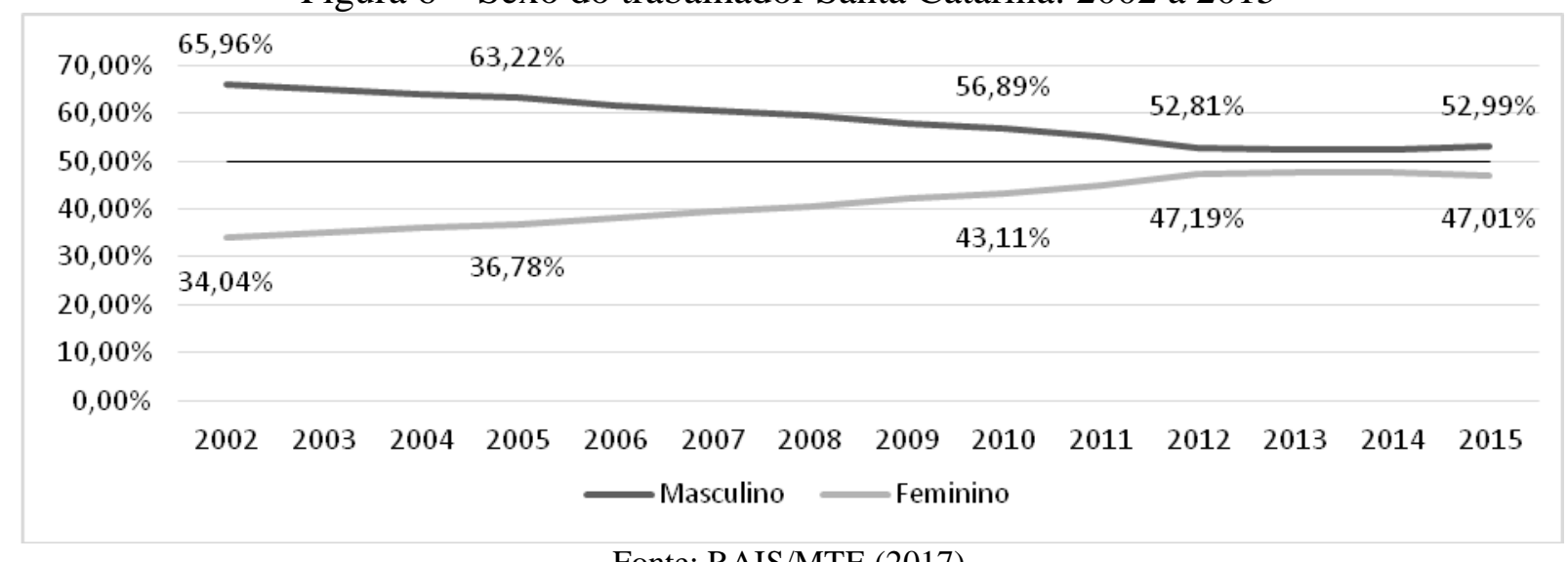

Fonte: RAIS/MTE (2017)

Em relação ao número de contratações, as cooperativas catarinenses que mais contrataram trabalhadores foram as pequenas, concentrando $82,92 \%$ das contratações em 2015 - entre 1 a 49 Vínculos Ativos, conforme tabela 4. No período de 2002 a 2015, houve redução absoluta e relativa $(30,11 \%)$ da participação das cooperativas de 1 a 4 Vínculos Ativos. Em compensação, as cooperativas de maior porte obtiveram aumentos absolutos e também relativos. Essa mudança na distribuição aponta para a direção de cooperativas que estão contratando mais trabalhadores para prestar seus serviços.

Tabela 4 - Porte dos estabelecimentos: 2002, 2005, 2010 e 2015

\begin{tabular}{lcccccccc}
\hline Tamanho Estabelecimento & 2002 & $\%$ & 2005 & $\%$ & 2010 & $\%$ & 2015 & $\%$ \\
\hline 0 Empregado & 20 & 3,00 & 36 & 4,28 & 28 & 2,61 & 45 & 3,59 \\
De 1 a 4 & 246 & 36,88 & 294 & 34,92 & 348 & 32,40 & 323 & 25,78 \\
De 5 a 9 & 159 & 23,84 & 198 & 23,52 & 258 & 24,02 & 292 & 23,30 \\
De 10 a 19 & 126 & 18,89 & 145 & 17,22 & 187 & 17,41 & 251 & 20,03 \\
De 20 a 49 & 73 & 10,94 & 105 & 12,47 & 140 & 13,04 & 173 & 13,81 \\
De 50 a 99 & 26 & 3,90 & 37 & 4,39 & 67 & 6,24 & 97 & 7,74 \\
De 100 a 249 & 8 & 1,20 & 18 & 2,14 & 30 & 2,79 & 40 & 3,19 \\
De 250 a 499 & 4 & 0,60 & 2 & 0,24 & 8 & 0,74 & 19 & 1,52 \\
De 500 a 999 & 3 & 0,45 & 4 & 0,48 & 4 & 0,37 & 4 & 0,32 \\
1000 ou Mais & 2 & 0,30 & 3 & 0,36 & 4 & 0,37 & 9 & 0,72 \\
\hline Total & 667 & 100,00 & 842 & 100,00 & 1074 & 100,00 & 1253 & 100,00 \\
\hline
\end{tabular}

Os dados apresentados anteriormente demonstram que o sistema Ocesc representa uma parte das cooperativas catarinenses, quando se compara com os números da RAIS. Já a outra rede de cooperativas, a União das Cooperativas da Agricultura Familiar e Economia 
Solidária do Estado de Santa Catarina (Unicafes/SC), também não abarca a totalidade, porque muitas cooperativas não estão filiadas a nenhuma das duas redes.

A seguir serão apresentadas informações referentes à Unicafes, que foi constituída para dar visibilidade e ser um instrumento de representação dos interesses das suas cooperativas afiliadas. Criada em 28 de julho de 2006, a Unicafes representa, atualmente, 97 cooperativas que integram os segmentos crédito, comercialização, produção, serviços, habitação, trabalho e fabricação. Sua sede está localizada na cidade de Chapecó, no Oeste de Santa Catarina.

A Unicafes representa organizações do cooperativismo da Agricultura Familiar e Economia Solidária e promove discussões para formulação e implantação de políticas públicas relacionadas ao cooperativismo e aos processos de desenvolvimento do setor.

Conforme dados da figura 7, dos 184 estabelecimentos vinculados à Unicafes, 94 tinham 60 ou mais sócios; isso representa $51 \%$ dos EES, sendo que $11 \%$ tinham até 10 associados.

Figura 7 - Número de cooperativas da agricultura familiar por faixa de número de sócios em Santa Catarina

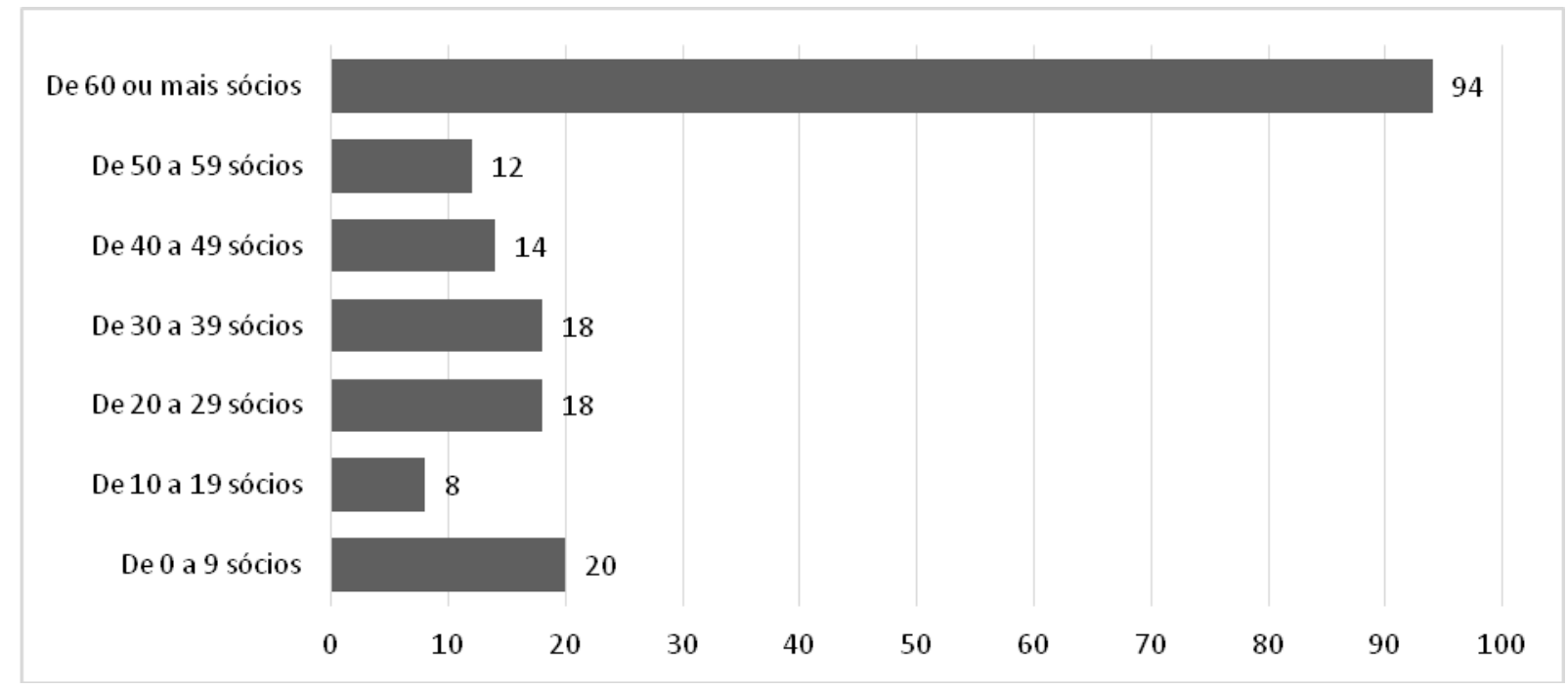

Nota: valores acumulados até o mês de divulgação; valores em números absolutos

Fonte: DIEESE - Observatório Nacional da Economia Solidária e do Cooperativismo: 2009 a 2013

Em relação ao sexo dos associados dos EES vinculados a Unicafes, com base nos números da figura 8, verifica-se a predominância de homens (66,7\%) nas cooperativas; apenas 33,3\% eram mulheres. As mulheres eram maioria apenas nos grupos informais, representando $53,2 \%$, enquanto os homens somavam $46,8 \%$. 
Figura 8 - Número de sócios em EES do tipo cooperativa, segundo o sexo, em Santa Catarina: 2013

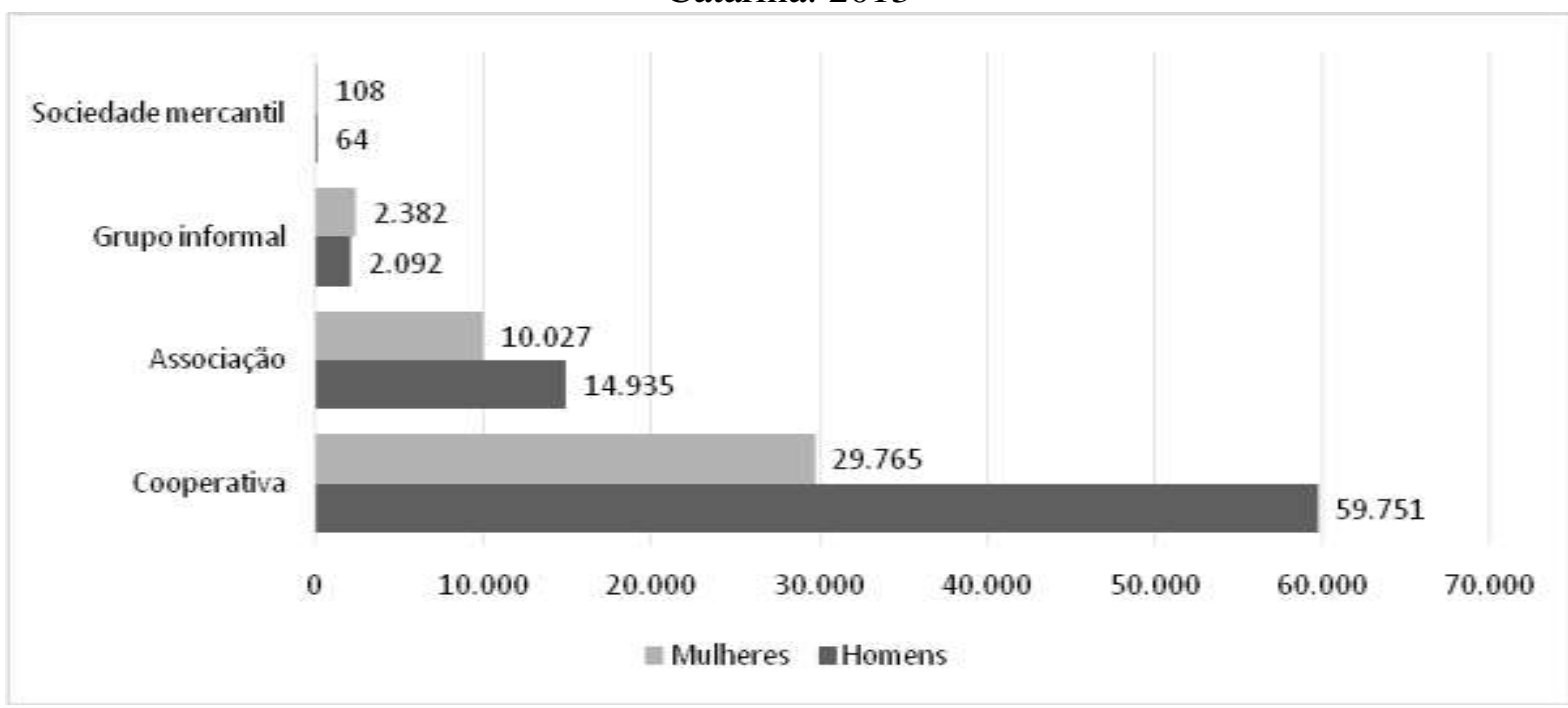

Nota: admite múltipla resposta

Fonte: DIEESE - Observatório Nacional da Economia Solidária e do Cooperativismo. Ano(s): 2009 a 2013

Ainda sobre os números da figura 8, cabe destacar a grande quantidade de associações, são quase 25 mil em todo o Estado. Esse resultado demonstra um considerável grau de fragilidade institucional dos empreendimentos. Embora as associações se constituam em uma alternativa intermediária de formalização, dada a sua simplicidade jurídica, são organizações limitadas em termos de atividade comercial, por não poderem exercer atividade econômica, como, por exemplo, emitir nota fiscal de seus produtos. No mapeamento, foram observados 4.474 grupos informais. A situação desses empreendimentos é bem mais difícil se comparada à das associações, pois, além de eles não poderem comercializar a produção, têm o acesso a financiamentos e a programas governamentais de apoio extremamente limitados. Essa realidade é devido ao excesso de procedimentos burocráticos para a formalização de cooperativas no País e à complexidade administrativa exigida, que fazem com que muitos empreendimentos não se sintam motivados a despender tempo e recursos adicionais para realizar essa formalização, mantendo-se como associações ou mesmo na informalidade (SILVA; CARNEIRO, 2016).

Os dados da figura 9 ilustram o número de EES por atividade e sua participação em relação ao total. Quanto à atividade econômica principal, destaca-se a produção ou a organização da comercialização $(43,4 \%)$, comercialização ou organização da comercialização $(27,5 \%)$, respectivamente. As atividades de poupança, crédito ou finanças solidárias $(14,3 \%)$ e prestação de serviço ou trabalho a terceiros $(12,7 \%)$ dividem o terceiro e quarto lugar. 
Figura 9 - EES por atividade econômica principal, em cooperativas, em Santa Catarina: 2013

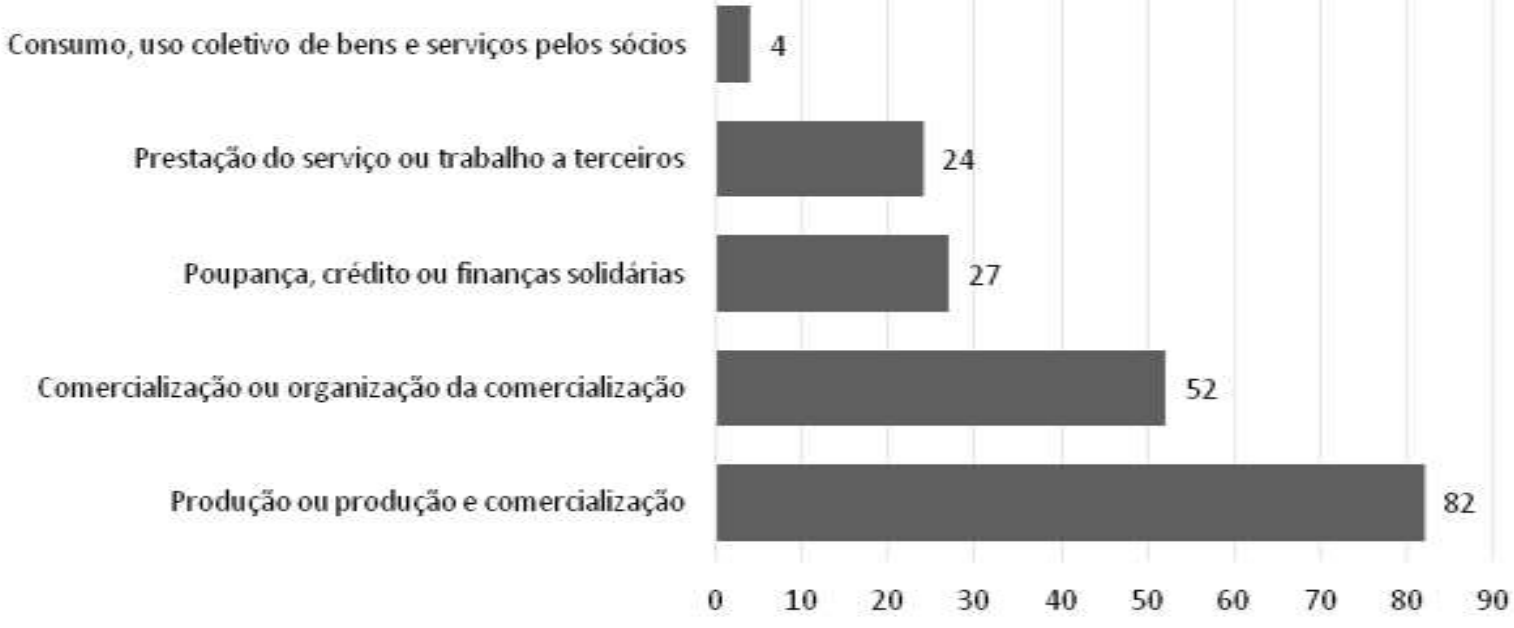

Valores em números absolutos

Fonte: DIEESE - Observatório Nacional da Economia Solidária e do Cooperativismo; ano(s): 2009 a 2013

Apesar da existência de cooperativas vinculadas à Ocesc e à Unicafes, em Santa Catarina, muitas cooperativas não são filiadas a nenhuma das duas redes. Existem outras redes de cooperação, como a Central das Cooperativas da Agricultura Familiar (Cecaf), no Oeste do Estado, e a Cooperativa Central da Agricultura Familiar e Economia Solidária do Estado de Santa Catarina (Coopercafes), no Sul do Estado. Essas duas redes representam em torno de cinquenta cooperativas.

Em 2010, em um estudo realizado pela Epagri, evidenciou-se a existência de um processo de reinserção no mercado, constituído por associações e cooperativas vinculadas ao meio rural. Conforme os dados do levantamento, tratava-se de mais de quatrocentos empreendimentos, dos quais mais de cinquenta por cento eram associações, trinta por cento eram constituídos por cooperativas (por produto e descentralizadas), e o restante dividia-se em condomínios, filiais de cooperativas. Em relação às cooperativas descentralizadas, estas atuavam na organização da produção e, principalmente, na comercialização de produtos da agricultura familiar. As cooperativas por produto predominavam na organização dos produtores de leite e de orgânicos (MIOR et al., 2014).

\section{Considerações finais}

Transcorridos mais de cento e cinquenta anos, o cooperativismo ainda é pouco compreendido no campo da economia. Na maioria das vezes, o tema é abordado sob o aspecto doutrinário, o que dificulta as análises e sua compreensão como uma organização socioeconômica importante na atualidade. 
No artigo, buscou-se apresentar informações sobre a diversidade do cooperativismo brasileiro e catarinense. Como se pôde observar no decorrer do artigo, o cooperativismo atual tem uma grande diversidade, por isso os dados, quando estudados, devem fazer referência ao segmento que se está abordando.

Como foi destacado, existe uma variabilidade de cooperativas espalhadas pelo País, mas é possível agrupá-las em duas tendências, uma formada por "cooperativas empresariais", com uma estrutura organizacional racional/burocrática, que beneficia certo número de sócios e utiliza força de trabalho assalariada, embora com menos intensidade que as empresas. A cooperativa é uma forma de integração horizontal, cujos sócios não participam de seu processo produtivo como trabalhadores. Nesse caso, a cooperativa é apenas uma alternativa para ganho de escala e obtenção de vantagens na comercialização.

O outro movimento é formado pelas cooperativas de Economia Solidária, outra forma de organização e produção que busca, por meio da cooperação, uma alternativa de trabalho e renda. Essas cooperativas também são denominadas sociais por se organizarem com o foco voltado para a questão social. Esse movimento se apresenta como um caminho para um desenvolvimento mais humano, centrado nas pessoas e não no capital.

\section{Referências}

BENINI, É. A.; BENINI, E. G. A construção do trabalho associado sob a hegemonia estatal: organização, solidariedade e sociabilidade. Revista O \& S, Salvador, v. 22, n. 74, p. 325-344, jul./set. - 2015. DOI: 10.1590/1984-9230742. Obtido em: < http://www.scielo.br/pdf/osoc/v22n74/1413-585X-osoc-22-74-0325.pdf >. Acesso em: 17 fev. 2017.

BIALOSKORSKI NETO, S. Economia e Gestão de Organizações Cooperativas. 2. ed. São Paulo: Ed. Atlas, 2012.

Um ensaio sobre desempenho econômico e participação em cooperativas agropecuárias. Revista de Economia e Sociologia Rural, Rio de Janeiro, v. 45, n. 01, p. 93-118, jan./mar. 2007.

BRASIL. Ministério do Trabalho e Emprego. Programa de Disseminação das Estatísticas do Trabalho. RAIS - Relação Anual de Informações Sociais (on line). 2002-2015. Obtido em: < http://bi.mte.gov.br/bgcaged/inicial.php > Acesso em: 25 fev 2017.

CRÚZIO, H. O. Como organizar e administrar uma cooperativa: uma alternativa para o desemprego. 3. ed. Rio de Janeiro: Editora FGV, 2002.

DIEESE. Observatório Nacional da Economia Solidária (on line). 2009 a 2013. Obtido em: < http://ecosol.dieese.org.br/indicadores.php > Acesso em: 25 fev 2017.

ETGETO, A. A. et al. Os princípios do cooperativismo e as cooperativas de crédito no Brasil. Maringa Management: Revista de Ciências Empresariais, v. 2, n.1, p. 7-19, jan./jun. 2005. Obtido em: 〈http://www.maringamanagement.com.br/novo/index.php/ojs/article/viewFile/30/15 > . Acesso em: 20 fev. 2017.

GAIGER, L. I. O mapeamento nacional e o conhecimento da economia solidária. 2013. Obtido em: < http://base.socioeco.org/docs/ ojs index.pdf >. Acesso em: 22 fev. 2017.

OCB. Agenda Institucional do Cooperativismo. Edição 2015. Obtido em: < http://www.brasilcooperativo.coop.br/GERENCIADOR/ba/arquivos/agenda_institucional_do_coop erativismo_2015.pdf>. Acesso em: 15 fev. 2017. 
Agenda Institucional do Cooperativismo. Edição 2016. Obtido em: <http://www.brasilcooperativo.coop.br/site/ocb_congresso/downloads/Agenda_2016.pdf > cesso em: 28 fev. 2017.

OCESC. Estatística do Cooperativismo Catarinense. Florianópolis: Ocesc, 2015. Obtido em: < http://admin.ocesc.org.br/padrao_itens/arquivos/107.pdf > Acesso em: 25 fev. 2017.

MIOR, L. C. et al. Inovações organizacionais da agricultura familiar no sul catarinense. In: ESTEVAM, D. O.; MIOR, L. C. (Orgs.). Inovações na agricultura familiar: as cooperativas descentralizadas em Santa Catarina. Florianópolis: Insular, 2014.

PINHO, D. B. O cooperativismo no Brasil: da vertente pioneira à vertente solidária. São Paulo: Saraiva, 2001.

O pensamento cooperativo e o cooperativismo brasileiro. 18 ed. São Paulo: $\mathrm{CNPq} / \mathrm{BNCC}, 1982$.

RIOS, G. S. L. O que é cooperativismo. 2. ed. São Paulo: Brasiliense, 1989.

SABINO, B. S. et al. Economia solidária: um breve estudo sobre as cooperativas catarinenses. In: ENCONTRO DE ECONOMIA CATARINENSE, 3., 2009, Blumenau. Anais... Blumenau: APEC, 2009. Obtido em: <www.apec.unesc.net/III\%20EEC/sessoes_tematicas/Social/Artigo\%2041.doc〉. Acesso em: 22 fev. 2017.

SILVA, S. P.; CARNEIRO, L. M. Os novos dados do mapeamento de Economia Solidária no Brasil: apontamentos iniciais para o debate. Brasília: IPEA, 2016. Obtido em: < http://repositorio.ipea.gov.br/bitstream/11058/3757/1/bmt57_novosdados.pdf >. Acesso em: 22 fev. 2017.

SINGER, P. Introdução à economia solidária. São Paulo: Fundação Perseu Abramo, 2002.

STAHL, R. L.; SCHNEIDER, J. O. As interfaces entre cooperativismo e economia solidária. Ciências Sociais Unisinos, São Leopoldo, v. 49, n. 2, p. 197-206, maio/ago. 2013.

YIN, R. K. Estudo de caso: planejamento e métodos. 2. ed. Porto Alegre: Bookman, 2005.

ZYLBERSZTAJN, D. Quatro estratégias fundamentais para cooperativas agrícolas. Anais do Seminário de Política Econômica: Cooperativismo e Agronegócio, Viçosa, MG, 2002. Obtido em: < file:///C:/Users/Casa/Downloads/4+estrat\%C3\%A9gias+para+cooperativas.pdf > Acesso em: 28 fev. 2017. 